\title{
COMPARISON OF PERCEPTIONS OF THREATS TO EXTERNAL SECURITY: STRATEGIC DOCUMENTS OF THE EUROPEAN UNION AND POLAND
}

\author{
Tadeusz ZIELIŃSKI, PhD \\ War Studies University, Warsaw, Poland \\ t-zielinski@akademia.mil.pl
}

\begin{abstract}
The article presents opinions and interpretations relating to the perception of threats to external security of the European Union (EU) and Poland. These are based on a comparison of the content of their strategic documents on the area of security. Despite the fact that Poland is a member of the EU it points out different attitude to threats assessment comparing those indicated in strategic documents of the EU. The EU security strategies and the security strategies of the Republic of Poland will be analysed. The time period taken was from the end of the Cold War until the current strategic documents were published. The perception of threats to the external security of the EU and Poland was correlated with the results of public opinion polls of the member states of the EU and Poland. The general findings lead to the conclusion that the perception of threats to external security contained in the strategic documents of the entities concerned is basically the same, but they perceive differently their priorities in reducing the risks associated with the occurrence of specific threats. Besides, Poland is more focused on military than none-military threats to its security especially from Russia's side.
\end{abstract}

Keywords: European Union (EU) strategies, external security, Poland's security, threats to global security, security strategy.

\section{Introduction}

The objectives and main directions of action of states and international organizations make up the content of strategic documents and they are a source of narrative about the identity of those entities. As a rule, they contain key information relating to the assessment of the security environment, including external, taking into account global challenges and threats, the strategic 
objectives of the given organization and the resulting implications for the organization. This information was and is included in both the strategies of the European Union, as well as Poland. What is more, there is a correlation between these documents, especially after the end of the Cold War. This is understandable because the vast majority of the countries are both the EU members, including Poland. On the other hand, Poland indicates different approaches based on its own perception of threats to external security. Thus, these attitudes might be interesting for further analysis.

The key content contained in the strategic documents of the EU and Poland refer to the anticipation of their external security environment. These assessments are carried out by teams of experts based on past and current events, mainly in the fields: political, economic, social and military (security). Unfortunately, in most cases they are reactive, with little anticipation of future threats to global security. On the other hand, the catalogue of security threats has definitely expanded due to new dangers, but also due to a broader understanding of security itself, understood as an interdisciplinary concept. Thus, security threats no longer include only military elements, but they constitute a whole register of identified and anticipated risks that may lower the level of acceptable threat to the external security of entities. This evolutionary approach is also evident in the strategic documents of the EU and Poland in the post-Cold War period.

The contemporary global security environment is exposed to a number of threats that may negatively affect its level. These phenomena are not entirely new, some of them have been functioning in the consciousness of societies for many decades, others have emerged recently, and some are not yet predictable. All of them have a significant impact on the perception of international security, and the repercussions associated with them affect many countries. Anticipating threats to the international security environment is extremely difficult, and their mere articulation depends on the researcher's approach.

\section{Materials and Methods}

Description and assessment of threats resulting from strategic documents of the EU and Poland requires references to the strategy itself as a key document identifying an international organization (European Union) or a state (Poland) - actors in international relations.

In classic term, strategy focused on war: peacetime defence planning and preparation, and guiding the military effort during a war to achieve victory. Nowadays, the strategy must 
correspond to complexity of the security environment and the scale of difficulty of regulating and managing this environment. The strategy must take into account the fact that the international security paradigm is evolving, the potentials and capabilities of many actors (not only superpowers, also middle states) are shifted, new areas for foreign policy and interest play on the international arena are opening up. In particular, strategy (as a document) diagnoses and defines security conditions, paying attention to the risks and threats, as well as the possibilities and chances of shaping the security environment in the manner most compatible with the national interest. Each strategy is a deliberate, planned activity that determines resources, capabilities and opportunities for action, as well as ways of coping with difficulties and challenges. The latter usually refer to the sources of weakness, instability and tensions, pointing to violence and armed conflicts as extreme forms of insecurity and immediate threats. Such a document creates a framework for national and international policy aimed at ensuring the inviolability of the vital interests of the nation and the state (understood as a set of legal norms and institutions serving the will of the nation expressed in an unrestricted and legally permissible manner), as well as outlining the directions of constant and successful development.

Henry Kissinger (2017) defines strategy as the way in which society secures its future. In his view, strategy is a long-term concept that becomes a kind of guideline for foreign policy. He emphasizes that the strategy has a national character and, similarly to the policy to which it is subordinated, takes into account the environment in a broad sense, the entire spectrum of political, economic and military conditions, which makes it a "grand strategy". However, Kissinger also uses the term "strategy" in its narrower sense - as the use of military power. Thus, the strategy covers that part of the policy in which the military instrument is used to ensure national security. Kissinger's approach is also visible in building the EU security strategy and national strategies, including Poland's.

The starting point of each strategy is to define its own goals, which in the case of a security strategy means identifying and defining national interests (if we are dealing with a national security strategy, state security) or defining a mission (if we are talking about an international organization strategy) in relation to the identified threats and risks. The threats included in the EU and Polish strategies analysed in the article, constituting a starting point for defining vital interests and missions, lead to the conclusion that the strategies try to reconcile two approaches: realism and liberalism, which are expressed by interests and values. The last decade of the EU's functioning in 
the field of security has been a very practical and hard test of the approach to security adopted in Europe. This approach, represented in particular in the European Security Strategy of 2003 (ESS), was dominated by the liberal concept, and in it the belief that values are the most important thing and that around their confession one can build a community action in the field of security as well. The practice of various crises and conflicts has shown that states in the face of a serious threat, however, act in accordance with the theory of realism rather than liberalism (idealism), i.e. they are primarily guided by strategic national interests. The current approach to the European strategy is therefore based on the lessons of recent years. There are two main approaches in defining the EU's security missions: realistic and liberal. With this approach, the strategic mission of the EU in the area of security is expressed in providing its citizens and states with conditions for realization of their basic interests, which take into account the most important common values. A similar approach is represented by the recent national security strategies of Poland.

The aim of this paper is to compare content of the strategic documents of the EU and Poland in context of identified threats to external security. The time period taken was from the end of the Cold War until the current strategic documents were published, both in the EU and Poland. Considering the above, key strategic documents describing the visions of external security of the EU and Poland were analysed. In this case, these are the security strategies of the EU and security strategies of the Republic of Poland. The results of the analysis were compared to threats perceived by public opinion. In order to answer the research question: what are the main differences in perception of threats to external security arising from strategic document of the EU and Poland, two main strategies of the EU were analysed with theoretical methods such as analysis, synthesis and generalization. The first one was European Security Strategy entitled A Secure Europe in a Better World and the new EU strategy for security (Shared Vision, Common Action: A Stronger Europe. And the second, A Global Strategy for the European Union's Foreign and Security Policy), known as a European Union Global Strategy (EUGS). The main result is that the first strategy of the EU was a declarative tool with huge ambitions without chance to implement it as a whole. Threats identified and described inside the document referred mainly to none-military, for instance, terrorism. What is more, there is no information about possibility of large-scale conflict against any EU country. The second document is more realistic in respect of identified threats to the EU which encompasses whole spectrum of none-military and military risks to the EU. Analysis of the five Security National Strategies of Poland leads to conclusion, that threats to external 
security of Poland, described into the documents are similar to those identified in the EU strategies. It is obvious, due to the fact that Poland is a member of the EU. However, polish documents are stronger in expressing opinion related to military threats from Russia side. Comparison the EU's and Poland's strategies led to conclusion that despite of the same understanding of threats to external security there is no consensus which of the are more important with high priority to individual countries of the EU.

Threats identified into the EU's and Poland's strategic documents were confront with opinion poll. I used secondary data from European Council on Foreign Relations and Polish Public Opinion Research Centre. What is interesting, survey of opinion in context of perceptions of security by society, comparing to threats identified into strategic documents both the Eu and Poland differentiate. It results from the fact, that surveys are often conducted in the aftermath of events which may influence sense of security or threats.

\section{Identification of threats to external security in the content of the European Union}

\section{strategies}

Three key stages can be distinguished in the EU approach to security, including defence in the strategic dimension. Koziej (2018) indicates the pre-strategic stage, the declarative strategy stage and the current stage of initiative strategy. The first stage covered the period up to 2003 when the EU did not have a security (defence) strategy and the tasks in this area were carried out by the Western European Union. This constituted a political and defensive organization guaranteeing Member States defence "services". During this period, the collapse of the bipolar international order, after the end of the Cold War, contributed to the "thaw" of multifaceted needs and interests of nation states - conflicts in new forms were revived again, and new types of threats appeared. A common feature of the conflicts that emerged after the end of the Cold War was, as a rule, their internal dimension, based on ethnic, cultural and religious differences. As a result, there was a redefinition of the classic threats, understood as military (mainly armed aggression), in the direction of non-military threats.

The second stage covered the period from 2003 when the EU adopted its first Security Strategy - ESS entitled A Secure Europe in a Better World. European Security Strategy. The authors of the ESS indicated globalization as the main factor of the changes taking place, in both positive and negative senses. In their opinion, globalization processes have, on the one hand, 
contributed to the socio-economic development of many societies, and on the other, have deepened cultural, economic and social differences, becoming a source of new conflicts. The ESS also identified many security threats and challenges. One of the threats referred to in the ESS is the proliferation of weapons of mass destruction treated at that time as potentially the greatest danger to the EU security, especially in relation to non-state actors. Terrorism and organised crime are equally important threats identified in the ESS (European Security Strategy 2003). The authors of the ESS also indicate security threats in cyberspace, warning against possible attacks on critical infrastructure of the EU member states. The problem of internet crime, including that carried out on private or government IT systems in the EU Member States, is also highlighted. In the opinion of the authors of the ESS, these activities give a new dimension as a potential new economic, political and military weapon. A lot of attention was paid in the ESS to energy security. Threats related to the EU Member States becoming dependent on the supply of energy resources from third parties represents a real threat of loss of energy security. The problem of progressive climate change and its impact on the EU security was treated as a challenge in the ESS (European Security Strategy 2003).

The ESS was devoid of implementation tools that would enable the actual implementation of the strategic goals. In the context of the threats identified, pointing only to the political will of the EU Member States proved to be far from sufficient. The weaknesses also include the lack of references to direct defence of the territory of the EU countries, as well as the categorical statement about the low probability of large-scale aggression against any EU country. Defining the EU as a global security entity, thus having a real (at least in theory) impact on shaping the international security environment, deserves positive assessment. Analysis of the document also leads to the conclusion that the adopted ESS is similar to the American strategy then in force. As Koziej points out (2018a), "it is expressed by, among others, highlighting the need for preventive action that can prevent more serious problems in the future. Although the EU experts are trying to show differences between the American strategy and the EU strategy, among others by diverging from the notion of 'pre-emptive actions', this clearly noticeable real conceptual convergence may indicate that the international community is gradually developing a common approach to security in the current environment."

Referring to threats, the content of the ESS seems too categorical in terms of stating that large-scale aggression against any EU country is unlikely. It is true that, in retrospect, that such an 
event did not take place, but the strategic document should contain a more balanced assessment, indicating the low probability of such aggression in the short and medium term (several, maybe even several years). On the other hand, the new quality of contemporary threats, which are more diverse, less visible and less predictable, largely asymmetrical, has been properly emphasized.

The weaknesses of the strategy include the complete omission of the issues of direct defence of the territory of EU countries against various threats, including, for example, terrorist attacks. It concerns both military and non-military issues, e.g. border protection, air protection, anti-missile defense, anti-terrorist operations, defence against weapons of mass destruction, civil protection, disaster recovery, etc. Internal (national) security is, after all, an integral part of the security of the EU.

There is a noticeable tendency related to security matters included in the ESS to American approach. It is expressed in emphasizing the need for preventive measures that can inhibit more serious problems in the future, and it shows that a transatlantic approach to this issue is gradually taking shape. On the other hand, the strategy itself remained in fact a political and strategic manifesto, without implementation instruments. Therefore, it was of little practical importance. This is because the EU and the documents it issues are one thing, and practice is another. There are too many references to "declarative" values in the ESS, and not enough real assessment of the future international situation and lack of real proposals related to improving the security of the EU and its member states. This is the result of the EU adopting a liberal model of international policy making rather than currently dominant realistic approach.

Regardless of the assessments, the ESS was the first document containing the word "strategy" in the security context, and thus setting the direction for the EU to function in a global security environment. This environment has turned out to be much more complex, dynamic and turbulent in the last dozen or so years of functioning of the EU, which is why the contents of the ESS from 2003 have become at least inadequate to the political, social and economic changes taking place (Terlikowski 2015). The redefinition of threats was caused primarily by the RussianGeorgian war in 2008, the economic crisis in the years 2007-2009 with its long-term consequences for security (with even a reduction in defence spending), the negative consequences of Arab Spring (civil war in Syria, Libya, Yemen) and, above all Russia's neo-imperialist policy, manifested in the annexation of the Crimea in 2014 and support for separatists in eastern Ukraine. These factors have become the reason for the start of work on a new security strategy, which opens a third stage 
- an initiative strategy that begins the implementation of practical solutions in the field of the EU security.

Analysis of the new EU strategy for security (Shared Vision, Common Action: A Stronger Europe. A Global Strategy for the European Union's Foreign and Security Policy), often referred to as a global strategy (European Union Global Strategy, EUGS) leads to the observation that the perception of threats to the environment of European security in relation to those contained in the previous document has not significantly changed (Archick 2018). Despite the above-mentioned factors determining the development of a new the EU security strategy, threats related primarily to transnational terrorism, organised crime and the proliferation of weapons of mass destruction continue to be at the forefront (European Union Global Strategy 2016). These threats are also valid today, as evidenced by the unforeseen nuclear tests conducted by North Korea, Iran's activities in the area of weapons of mass destruction and terrorist attacks that took place in the capitals of European cities. The dangers related to economic instability and ensuring energy and cyber security, as well as climate change, which may be the cause of further threats, among others related to migration, are further justified. Among the newly identified threats are hybrid threats which appear as a consequence of actions taken by Russia (Piskorska 2018). In the European Union Global Strategy (2016), Russia was indicated as a state that "violated international law and caused the destabilization of Ukraine." It has also been clearly articulated that the EU "will not recognise Russia's illegal annexation of Crimea or reconcile with the destabilization of eastern Ukraine." On the one hand, the content of the EUGS does not define Russia as a threat (relations with it are defined as a "strategic challenge"), on the other, however, the areas of activity that have been identified as priority overlap with the areas of Russian activity referred to as a hybrid war. The document emphasises the need to invest in both military capabilities as well as cyber and energy security. The second area of geographical threats relates to the Mediterranean basin, the Middle East and parts of Sub-Saharan Africa, from where challenges to EU security arise, related primarily to migration (European Union Global Strategy 2016).

The taking of practical steps by the EU in the field of security aimed at preventing the identified threats to security, is based is on the implementation of four priority areas for EU action: 1) lawful global governance, 2) democracy, 3) well-being, and 4) internal and external security of the citizens and the Member States. In turn, the strength of the EU as a security entity in the international environment depends in the main part on its credibility, activity and consistency of 
actions, because "none of our countries alone have sufficient power or resources to deal with these threats and exploit the opportunities of our time" (Wróblewska-Łysik 2016).

It seems that the perception of threats to the EU's external security environment has been treated too superficially in the EUGS. From Poland's perspective, as a NATO flank state, Russia's confrontational policy, including its military activities, should be treated by the authors of the EUGS in a particular way (Koziej 2017). In the author's opinion, in the EUGS decidedly more prominence is given to the threats associated with the southern flank (equally important), and so to the threats linked to uncontrolled migration and its potential negative consequences.

The principles of the global security system, which was also built by Europeans, are eroding or falling apart. The rivalry between economic and military global powers directly affects the $\mathrm{EU}$, and threats related to international terrorism, cyberattacks as well as climate change raise further concerns in EU Member States (Koziej 2018). This is evident in the content of the EUGS, which identifies threats both to the east and to the south of the continent and indicates the uncertainty associated with the ally to the west - the United States. The articulation of threats to European security in the EUGS is a consensus among individual Member States, which was described in the strategy in a politically correct way. In fact, there are differences in the perception of threats to EU external security. For example, EU Member States in the neighbourhood of Russia perceive this country as a real threat to their security, including the possibility of violating their territorial integrity (Buzanski 2018). In southern Europe, on the other hand, uncontrolled migration from the Middle East is considered a greater threat, hence the cooperation of these countries with the increasingly autocratic regime in Ankara. In turn, conflicts and poverty on the other side of the Mediterranean and the resulting migration increasingly threaten Europe's security and even its solidarity. The uncertainty is also tied to the unpredictable behaviour of the President of the United States, who shows disregard for international treaties and standards that for Europeans are indisputable. The unilateral withdrawal of the US from the Iran nuclear deal, and earlier exit from the climate agreement, the trade war with China and Iran are just some examples that require Europeans to reconsider the issues of their security. These voices are also heard in the content of the EUGS, but Europeans themselves are divided on the perception of threats to the EU security. The political crisis related to uncontrolled migration in 2015 revealed fundamental divisions related to the way Member States view their security. Krastev $(2017,25)$ point out "The refugee crisis exposed the futility of the post-Cold War paradigm, and especially the incapacity of Cold 
War Institutions and rules to deal with the problems of the contemporary world". For many Europeans, the migration crisis has shown the lack of capacity of the EU and the global system to deal with such problems, but it also affected internal divisions in individual countries.

The content of EUGS might be fully implemented through the preparation of specific strategies, plans and implementation programs, including in the first place sectoral and geographic strategies. An example of such a strategy is the constantly developed and implemented Maritime Security Strategy of 2014. However, a great challenge is for preparation of the EU Defence Strategy (CSDP strategy) in a short time. Daniel Keohane and Christian Mölling (2016) consider four options for approaching the preparation of such a strategy: conservative, comprehensive, ambitious and realistic. The first approach - conservative - is based on taking into account the existing EU structure and basically assumes the continuation of the classic CSDP as a crisis management system. The comprehensive approach takes as a starting point the assessment of threats and risks to European security and suggests broadening the strategic interest of the EU beyond defensce issues, including those related to universal values, norms and global goods, which would require the construction of new measures and instruments, as well as significant institutional changes. The ambitious approach is based on the need to be guided by the interests (the mission of the EU) and proposes to expand the current main goals, tasks and capabilities, including concerning defence spending, cybersecurity, contribution to common strategic deterrence with NATO, or the ability to independently conduct external military operations. A realistic approach calls for relying on the existing and possible future capabilities of the Member States and on this basis determining in what situations and how the EU can conduct defense operations, being aware that this will mean lowering the level of ambition and giving up the EU's global role. Regardless of the general option of approaching works on defence strategy, their starting point should be identification of a catalog of common and non-conflicting national interests of the Member States, allowing for the definition of a realistic strategic mission of the EU in the field of defence (in the scope of the CSDP).

Preliminary assessing the implementation of the EUGS leads to conclusion that in terms of intentions and plans these actions look promising. The EU has clearly become active. There is a will to create the conditions for the EU to become an organized strategic actor in security practice.

At present, it seems that the EU is generally agreed on the growing threats to its security. In a study conducted by the European Council on Foreign Relations (ECFR) respondents from the 
EU Member States stated clearly that the threat to their countries in the period 2008-2018 strongly intensified, and in their opinion it will be deepened in the next decade (Dennison, Franke, and Zerka 2018). According to the respondents, currently the top five threats to the EU security are, in descending order: cyberattacks, the collapse of states and civil wars in the immediate vicinity of the EU, the interference of external entities in the internal politics of the EU Member States, uncontrolled migration to the EU Member States, deterioration of the international order and institutional order. Further significant threats considered are: terrorist attacks, interstate conflict, the disintegration of the EU, the lack of resistance of state apparatus and social instability, financial instability, disruption in the supply of energy, climate change, nuclear attack on a country or ally. Respondents indicated that in the coming decade the identified threats to the EU security will be largely the same (Dennison, Franke, and Zerka 2018). The researchers conducting the survey assessed that the degree of perception of threats to the security of the EU Member States in 2018 is slightly different than that assessed in 2008, when the most important threats were considered to be (in descending order) economic instability and terrorist attacks, instability in the EU's immediate neighbourhood disrupting energy supply and cyberattacks. In other words, identifying security threats is closely linked to current events that occur before and during the research. In 2008, these were: the emerging economic crises and cyberattacks carried out on government institutions in Estonia in 2007 (Dennison, Franke, and Zerka 2018). Some threats can be considered universal, e.g. terrorist attacks, which are also reflected in the content of the EU strategic documents. In the context of the international situation, respondents indicated that one of the key threats to the EU security continues to be jihadists and related terrorist attacks, but also indicated the real threat from Russia and North Korea. Respondents said that these threats could persist for another decade until 2028.

The degree of perception of threats to EU security varies from one Member State to another (Krumm et al. 2019). There is widespread belief about divisions in security issues to the East, where the main threat is associated with Russia's aggressive policy, and to the South, where terrorism is recognised as the main threat. The ECFR study indicates that perception of threats is more complex, and the differences in their perception are not as obvious as a common narrative would suggest. Europeans in both the east and the south of the continent are concerned about uncontrolled migration to their countries. Slovenia, Austria, Bulgaria, Greece, Malta and Italy view this threat as the most significant for security issues. In turn, organised international crime comes 
to the fore as a threat among the southern the EU countries - Greece, Malta, Spain, but also in Slovakia and Austria. Fear of terrorism is particularly evident in countries that have recently experienced this type of attack, mainly in the United Kingdom, France, Spain, Germany, Denmark and Belgium. In the countries of the northern and eastern parts of the continent - Estonia, Romania, Lithuania, Poland and Finland, the unpredictable Russian policies are considered to the greatest threat, although in Germany and the UK, they are also regarded as a serious security threat. In addition, Lithuania and Estonia are particularly concerned about Russia's interference in the internal politics of these countries. Most of the countries surveyed also indicated the threat posed by Russia in the sphere of cyberattacks, the inability to respond to information action (disinformation), and susceptibility to influence of European public opinion (Dennison, Franke, and Zerka 2018).

The perception of security threats outside the EU articulated in its strategic documents do not keep up with the actual phenomena that occur in the environment of the EU, and which can directly affect the level of its security. As a rule, these are reactive assessments based on events that have already taken place and which may increase or recur. This is understandable because predicting future threats is extremely difficult. At the same time current events related to global security allow the articulation of "universal" threats, which can operate over a period of several years (decades) and which may be included in the strategic documents of the EU. The EU's security strategies (ESS, EUGS) seem to be politically correct, reconciling security concerns among individual Member States. Still, in the author's opinion, real military threats are articulated, to a small extent, aimed primarily at Central and Eastern Europe. In this context, there is a possible unfavourable scenario (disintegration) for Central and Eastern Europe, including Poland. Differences in perception of threats can lead to the EU security of "different speeds" and, in an extreme scenario, to the collapse of the European security system. As a consequence, a grey security zone may appear in Central and Eastern Europe, which everyone will know and accept by agreement, treating it as a kind of shield for other European countries. Such a possibility, although not very realistic, should also be considered.

\section{Identification of threats to external security in the security strategies of Poland}

Retrospection associated with the analysis of regulatory documents defining the security strategy of the Republic of Poland starts from 2000 when the first Security Strategy of the Republic 
of Poland (SSRP 2000) after the accession to NATO was published, together with the Strategy of Defence of Poland, representing the development of the sector in matters of national defence. The assessment of threats in the document is the result of the generally prevailing opinion that NATO is the main guarantor of Polish security, through a reduction in relation to the threat of aggression and the strengthening of deterrence. The changing nature of threats and challenges to the security of European countries is clearly indicated, downplaying the risk of global war in favour of an increased risk of local and regional conflicts for which Poland should be prepared. The key threats from the point of view of Polish security include: the proliferation of weapons of mass destruction, economic threats, uncontrolled cross-border migration, the existence of an excessive concentration of military capabilities in some regions, threats to the environment, terrorism and organised crime as well as the activity of foreign special services (Koziej and Brzozowski 2015).

The threat assessment presented in SSRP 2000 remains valid in many places. Nevertheless, in 2003 a new National Security Strategy of the Republic of Poland (NSSRP 2003) was presented, which in the context of the threat assessment took into account trends emerging after the terrorist attacks in the United States in September 2001. In the assessment of the threats contained in NSSRP 2003 first place is taken by global challenges associated primarily with the tensions and instability caused by international terrorism, proliferation of weapons of mass destruction and the phenomenon of failed or failing states. According to the authors of NSSRP 2003, Poland is also directly exposed to the resulting threats, and its security is increasingly dependent on the effects of globalization. International terrorism taking up modern technological solutions was recognised as the most serious danger, the effects of which are felt in individual countries in different ways. Proliferation of weapons of mass destruction was also identified as a threat, in particular the development of means of delivery. The document indicates that the territory of Poland may in the coming years be within range of ballistic missiles from outside Europe. In addition, terrorist organizations may gain possession of these weapons and their means of delivery. International crime (the smuggling of weapons, dangerous materials and human-trafficking, narco-business) is very strongly emphasised as a threat. This is due to the fact that Poland is a transit country and is becoming the subject of interest of international criminal groups. For the first time in a strategic document, threats in the IT sphere have been clearly articulated, indicating that Polish government institutions and its critical infrastructure may be the target of a cyberattack (Koziej and Brzozowski 2016). Also, the threat from broadly-understood ecology, including the degradation of the 
environment in the immediate surroundings, ecological disasters, large-scale air and water pollution, can intensify and pose a real danger in the country. Mass migration from poor and poorly developed countries resulting from local conflicts has been recognised as a serious threat, and the increase in "migratory pressure" may be a reason for the development of illegal trafficking in human beings (Koziej and Brzozowski 2016).

In the context of threat assessment, NSSRP 2003 shifts the focus from classic threats (armed aggression) to atypical threats, sources of which include non-state entities that are difficult to identify. The strategy emphasises to a greater extent threats to the sphere of internal security. It seems that the content of the document lacks assessment of threats to Poland and its allies in relation to classic armed conflict, which should never be overlooked in assessments related to Poland's security.

In 2007 a new National Security Strategy of the Republic of Poland (NSSRP 2007) was adopted, which was an expression of a new approach to the issue of national security, treated in an integrated manner. The authors of NSSRP (2007) indicate that "the security of Poland is influenced mainly by processes and phenomena in its surroundings - in the region, in Europe and within the Euro-Atlantic community". For the first time since the end of the Cold War, there is an expression of the threat from Russia in the context of energy policy and discrimination against some NATO and the EU members. There is a new category of threats - asymmetric, mainly related to non-state actors that are often difficult to identify. In the assessments of the authors of NSSRP (2007), regional and local conflicts as well as failed states that are unable to control their territory remain an important source of threats. The deepening disparities between rich and poor countries are causing tensions in international relations. The dependence of the Polish economy on the supply of energy resources (crude oil and natural gas) from one source (primarily from Russia) was considered the greatest threat to Poland's security in the NSSRP 2007. Subsequently, organised international terrorism and related organised crime, was indicated as retaliation for Poland's participation in NATO and the EU crisis response operations (National Security Strategy of the Republic of Poland 2007).

In the years 2010-2012, a Strategic National Security Review was carried out for the first time in Poland, on the basis of which the National Security Bureau developed the White Book of National Security of Poland. These formed the basis for the development of the next National Security Strategy of the Republic of Poland of 2014 (NSSRP 2014). The basis for the development 
of the new document were the assumptions of the so-called strategic return presented by the President of the Republic, defining new directions of activities of the state in strengthening its security, including national defence. The crisis of European security and NATO's adaptation to new security conditions also proved to be determinants of changes. A key factor influencing the need to develop a new strategic document should also be identified as the aggressive policy of the Russian Federation, manifesting, in the context of Polish security, militarization of its foreign policy in relation to its neighbours. As a consequence, the principles of international law are being undermined, including the post-Cold War order, and there is an increase in symmetrical and hybrid threats that may trigger crisis situations. In addition, Islamic extremism and terrorism are intensifying the threat to European security, including Poland. Therefore, in Newport (2014), the North Atlantic Alliance made key decisions to strengthen NATO's eastern flank and monitor relations with Russia.

In the assessment of Poland's security threats presented in NSSRP 2014, changes in the area of European security come to the fore, including in particular the crisis in Eastern Europe, the Middle East and North Africa. From the Polish perspective, the most serious dangers come from the Russian-Ukrainian conflict that could escalate the threat of aggressive actions by Russia toward countries in the region of Central and Eastern Europe. These activities may be strengthened by Russia with elements of an economic campaign, in particular access to energy resources. According to authors of National Security Strategy of the Republic of Poland (2014), the information campaign led by Russia directed against the countries of the region is a significant threat, along with political and military pressure exerted by demonstration of conventional and nuclear potential, including a large number of military exercises in the direct vicinity of Poland. The possibility of aggression below the war threshold (hybrid actions) are of clear concern, which could hamper the potential reaction of the North Atlantic Alliance under art. 5 of the Washington Treaty. The threat assessment also takes into account the dangers arising on the southern flank of Europe, including those associated with the so-called Islamic State, including in the form of terrorist activities. In global terms, it also points to the threats associated with the failure of international organizations responsible for security, the lack of decisiveness in the United Nations, as well as the increase in threats related to the undermining of the credibility of disarmament agreements, including those related to nuclear weapons (National Security Strategy of the Republic of Poland 2014). Generally speaking, NSSRP 2014 there is a visible focus on threats related to 
direct aggression on the territory of Poland or a country of the eastern NATO flank by a state entity, in this case Russia. The remaining types of threats correspond to those identified in earlier versions of the strategic documents.

Discussion on the new National Security Strategy of the Republic of Poland (NSSRP 2020) has been going on since the publication of the one from 2014. This is due to the changes in the contemporary international security environment and the near vicinity of Poland. New strategy was issued in May of 2020. The threats include uncertainty and failure to respect international law, as well as an increase in the number of threats. In particular, the policy of the authorities of the Russian Federation and its military aggression accompanied by the development of antiaccess/area denial systems and offensive military potential are mentioned. The document points to the following areas: the Kaliningrad Oblast and the Baltic Sea, military exercises based on conflict scenarios with the countries of the North Atlantic Alliance, rapid movement of large troops and the use of nuclear weapons. The strategy also points to Russia's aggressive hybrid activities, designed to destabilize NATO and its allied states, which pose a risk of conflict, including disinformation and cyber attacks. The persistent regional and internal conflicts in Europe's southern neighborhood also pose a threat. As a result, as well as due to the rapid population growth and differences in living standards, migration pressure has intensified, which remains a challenge for Europe's security. On a global scale, an important phenomenon is the intensifying strategic rivalry between the United States of America, the People's Republic of China and the Russian Federation, which affects the entire international system. There are new threats related to technological development: artificial intelligence, unmanned aerial vehicles and other robotic platforms, long-range precision weapons, including ballistic missiles and cruise missiles. The element of using nuclear weapons as an element of de-escalation of the conflict is also growing (National Security Strategy of the Republic of Poland 2020).

Compared to the previous strategies, the articulated threats mainly relate directly to external security, i.e. maintaining sovereignty and territorial integrity. The main threat in this context is the neo-imperial policy of the authorities of the Russian Federation, which is important in line with the way NATO started to perceive this situation. In addition, the Sino-US conflict and pandemic threats were noticed, but the threats resulting from the cyber area and the use of new technologies were treated marginally. 
The assessment of security threats to Poland presented in security strategies indicates they are identical with the feelings of public opinion, which have been tested in this regard in social research. In a study commissioned by the Kazimierz Pułaski Foundation (Smura 2018) in 2018, a question was put about the most important threat to the security of Poland and Poles. The respondents could choose from four possible answers (threats): migration crisis, the EU collapse, armed conflict with the Russian Federation and terrorism, which also appear in the security strategies of the Republic of Poland. The proportions of the possibility of occurrence of individual threats were distributed fairly evenly. 28.6 percent of Poles believed armed conflict with the Russian Federation to be the greatest threat to security, the migration crisis $-24.6 \%$, terrorism $23.3 \%$, and the break-up of the EU - 23.2\%. This study was conducted in January 2018 and repeated in March of the same year. In the March survey, the fear of armed conflict had increased quite significantly - to $36.8 \%$, and the fear of the migration crisis had decreased $(19.4 \%$ of respondents indicated it as the greatest threat). This change should be explained by the fact of the closing of the emigration route in the eastern Mediterranean and the reduction in the influx of migrants to Europe (Smura 2018). These results may change drastically under the influence of current political events in the world. An example would be a survey conducted by the Public Opinion Research Centre also in 2018, in which Poles were asked whether there is a threat to Poland's independence at present. Since April 2014, that is after the "referendum" in Crimea and the annexation of this peninsula by the Russian Federation, the level of fears of maintaining Poland's independence, which had not been recorded before, remains elevated. The results of the research from the last four years strongly contrast with those carried out in the years 1992-2013, when the vast majority of respondents claimed that there is no threat to Poland's independence. The worst assessment of the situation was in April 2014, when as many as $47 \%$ of respondents thought that there was a threat to Poland's independence, and 41\% did not agree (Public Opinion Research Centre 2018).

The exemplification of threats to Poland's security, presented in the security strategies and an informal document of the Ministry of National Defence, clearly indicates fears related to the danger of a conflict with a state entity that may take various forms, including hybrid actions. The possibility of armed conflict is decidedly more strongly articulated in normative documents in force in Poland compared to strategic documents in the EU. Poland perceives as decidedly more realistic the threats resulting from the immediate vicinity of Russia, whose unpredictable foreign 
policy may arouse and raises legitimate concerns about its external security. This is conditioned by historical experience, but also by an actual assessment of Russia's actions in close proximity to Poland.

\section{Conclusion}

Predicting future threats to the external security of entities (countries, organizations) is extremely difficult and is based primarily on the experience of researchers and the assessment of already existing adverse phenomena in relation to geopolitical trends (Zięba 2016; Coats 2018; The Global Risks Report 2019). The perception of threats to the external security of the EU, Poland or, in a broader dimension, global security is presented in strategic documents as an important element within the challenges that determine the strategic goals of a given entity. Their identification in relation to the discussed entities is essentially the same. This should not come as a surprise, since Poland is the EU Member, and in principle, profess the same so-called western values. The differences are visible in the assessment of which of the identified threats have a real impact on the external security of Poland. Hence, the first conclusion relates to the need to develop a catalogue of common threats to external security that will take into account the concerns of all countries and treat them in the same way. While there is no problem with identifying common threats to external security, their degree for individual countries currently differs diametrically. For example, from the point of view of the security of Poland - a state on the eastern flank of the EU and NATO - the narrative related to threats from the East, and above all Russia's unpredictable policy, is of key importance. Meanwhile, however, the EUGS clearly focuses on counteracting threats from the southern strategic direction, such as terrorism and illegal migration, as well as on stabilising the Mediterranean region and Africa. Therefore, establishing a common perception of threats and common priorities in their elimination is necessary and at the same time beneficial for the functioning of all members of the $\mathrm{EU}$, as it will strengthen their resistance to threats.

Another important aspect related to the perception of threats to the external security of the EU and Poland is associated with the need to strengthen cooperation between the EU and NATO, of which Poland is also a member. The scope of this cooperation will primarily be determined by the dynamics of relations between the two organizations, but also by the scale of US involvement in European security. Taking into account the very good relations between Poland and the USA, it should play a catalytic role to increase the scope of cooperation in the field of security for the 
Member States of the EU and NATO. Significant progress has been made in this respect since the end of 2016, including through joint NATO and the EU initiatives in the field of security and defence. Therefore, a common map of threats to security covering the Euro-Atlantic area is necessary, which will reconcile the often-divergent interests of individual states and the organizations to which they belong.

Simplifying on the issue of the perception of threats articulated in strategic documents of the EU and Poland, there is a visible change in the concept of their perception - from the centric (state or organization) to one directed towards the citizens. Although the very articulation of threats in strategic documents is often associated with the functioning of the state or organization, they are as a consequence perceived through their impact on the security of citizens. This may suggest that the state or organization is seen as relatively secure, while their citizens may be exposed to all kinds of dangers. In other words, this unit is in the centre of ensuring security, and it should focus the activities of the state or the organization, so it becomes the subject of security. This is particularly evident when it comes to articulating threats related to economic, social or political instability. On the other hand, ensuring the security and territorial integrity of the state (organization) translates into the security of its citizens.

Comparison of the perception of threats contained in strategic documents of the EU and Poland also leads to the conclusion that awareness of the significance of threats related to climate change is increasing. The consequences of the process of global warming and violent weather phenomena, occurring practically everywhere around the globe, will affect societies in many regions of the world, contributing to the development of crisis situations. Conflicts may arise due to the lack of resources necessary for survival; climate change will directly cause the emergence of economic damage or uncontrolled migration of people. It is appropriate that strategic documents articulate this type of threat, because it gives the opportunity to develop adequate prevention in advance.

The map of threats to external security of the EU and Poland articulated in strategic documents is in many places consistent for both sides. It is therefore a very good basis for consensus on identifying common threat areas and priorities for eliminating them to ensure security. 


\section{References}

1. $\quad$ Archick, K. (2018). "The European Union: Ongoing Challenges and Future Prospects." Report R44249. Washington D.C.: Congressional Research Service. https://fas.org/sgp/crs/row/R44249.pdf.

2. Buzanski, M. (2018). "Threat Perceptions and Scenarios for EU Security and Defense. Outcomes Report of the Mercator European Dialogue Workshop Brussels - 9 July 2018." Berlin: German Marshall Fund of the United States. https://www.mercatoreuropeandialogue.org/download-file/726/.

3. Coats, D. R. (2019). "Statement for the Record. Worldwide Threat Assessment of the US Intelligence Community, January 29, 2019." Washington D.C.: U.S. Senate Select Committee on Intelligence. https://www.hsdl.org/?view\&did=820727.

4. Dennison, S., Franke, U.E and Zerka, P. (2018). "The Nightmare of the Dark. The Security Fears that Keep Europeans Awake at Night." London: European Council on Foreign Relations. https://www.ecfr.eu/page/-/SECURITY_SCORECARD_267.pdf.

5. European Security Strategy 2003. "A Secure Europe in a Better World. European Security Strategy." Brussels: Council of the European https://www.cvce.eu/content/publication/2004/10/11/1df262f2-260c-486f-b414dbf8dc112b6b/publishable_en.pdf.

6. European Union Global Strategy 2016. "Shared Vision, Common Action: A Stronger Europe. A Global Strategy for the European Union's Foreign And Security Policy." Brussels: $\quad$ European $\quad$ External Action Service. http://eeas.europa.eu/archives/docs/top_stories/pdf/eugs_review_web.pdf.

7. Keohane, D. And Mölling, Ch. (2016). "Conservative, Comprehensive, Ambitious, or Realistic? Assessing EU Defense Strategy Approaches. " Policy Brief No. 41, 2016. https://www.gmfus.org/publications/conservative-comprehensive-ambitious-or-realisticassessing-eu-defense-strategy.

8. Kissinger, H.(2017). Dyplomacja [Diplomacy], Warszawa: Wydawnictwo Bellona.

9. Koziej, S. (2017). "Strategia globalna UE: szanse i dalsze wyzwania wdrożeniowe" [EU Global Strategy: Opportunities and Challenges of Further Implementation]. Pułaski Policy Paper. Warszawa: Fundacja im. Kazimierza Pułaskiego. https://pulaski.pl/wpcontent/uploads/2017/02/Pulaski_Policy_Papers_Nr_3_17.pdf. 
10. Koziej, S. (2018). "Ewolucja i scenariusze kształtowania się środowiska bezpieczeństwa europejskiego" [Evolution and Scenarios of Shaping of the European Security Environment]. In Bezpieczeństwo Europy $w$ globalnym świecie. Szanse i zagrożenia przyszłości w warunkach przesileń cywilizacyjnych [Europe's Security in the Global World. Opportunities and threats of the future in conditions of civilizational solstice], edited by KLEER, Jerzy And PRANDECKI, Konrad, 280-309. Warszawa: Polska Akademia Nauk.

11. Koziej, S. (2018a). "Ewolucja strategii bezpieczeństwa Unii Europejskiej" [European Union Security Strategy Evolution]. Myśl Ekonomiczna i Polityczna, 2(61), 197-230. doi:10.26399/meip.2(61).2018.23/s.koziej.

12. Koziej, S. And Brzozowski, A. (2015). "Strategie bezpieczeństwa narodowego RP 19902014. Refleksja na ćwierćwiecze" [National Security Strategies of the Republic of Poland 1990-2014. Quarter Century Reflection]. In Strategia bezpieczeństwa narodowego Rzeczypospolitej Polskiej. Pierwsze 25 lat [National security strategy of the Republic of Poland. First 25 years], edited by KUPIECKI, Robert, 17-54. Warszawa: Wojskowe Centrum Edukacji Obywatelskiej.

13. Koziej, S. And Brzozowski, A. (2016). "25 lat polskiej strategii bezpieczeństwa" [25 Years of Polish Security Strategy]. Bezpieczeństwo Narodowe, II-2014/30, 11-40. http://www.bbn.gov.pl/download/1/17028/11-40sSKoziejABrzozowski.pdf.

14. Krastev, I. (2017). After Europe. Philadelphia: University of Pennsylvania Press.

15. Krumm, R., Dienes, A., Weiß, S., Starystach, S., Schröder, H. and Bär, S. (2019). "Wakeup Call for Europe!" Vienna (Austria): FES Regional Office for Cooperation and Peace in Europe. http://library.fes.de/pdf-files/bueros/wien/15176-20190412.pdf.

16. "National Security Strategy Of The Republic Of Poland 2007". https://www.msz.gov.pl/resource/7d18e04d-8f23-4128-84b9-4f426346a112.

17. "National Security Strategy Of The Republic Of Poland 2014". from https:/www.bbn.gov.pl/ftp/SBN\%20RP.pdf.

18. "National Security Strategy Of The Republic Of Poland 2020". https://www.bbn.gov.pl/ftp/dokumenty/National_Security_Strategy_of_the_Republic_of _Poland_2020.pdf.

19. Piskorska, B. (2018). "Globalna strategia a redefinicja polityki Unii Europejskiej w jej sąsiedztwie" [Global Strategy and Redefinition of European Union Policy in its 
Neighborhood]. Roczniki Nauk Społecznych, 10(46), 67-90. doi: http://dx.doi.org/10.18290/rns.2018.46.1-4.

20. Public Opiniom Research Centre. (2018). "Polacy o NATO i bezpieczeństwie międzynarodowym. Komunikat z badań nr 71/2018" [Poles about NATO and International Security. Research report no. 71/2018 9]. Warszawa: Fundacja Centrum Badania Opinii Społecznej. https://www.cbos.pl/SPISKOM.POL/2018/K_071_18.PDF.

21. Smura, T. (2018). "Polityka zagraniczna i bezpieczeństwo zewnętrzne Polski - badanie opinii publicznej" [Poland's Foreign Policy and External Security - Public Opinion Polling]. Warszawa: Fundacja im. Kazimierza Pułaskiego, Selectivv Mobile House. https://pulaski.pl/wp-content/uploads/2018/03/e661d35d4de1cc10d22db11bfa2e4a07.pdf.

22. Terlikowski, M. (2015). "Navigating Through Threat Perceptions in Europe." Zürich: Eidgenössische Technische Hochschule Zürich. https://css.ethz.ch/en/services/digitallibrary/articles/article.html/195270/pdf.

23. "The Global Risks Report 2019". 14th Edition. Geneva: World Economic Forum. from http://www3.weforum.org/docs/WEF_Global_Risks_Report_2019.pdf.

24. Wróblewska-Łysik, M. (2016). "Europejska Strategia Globalna a możliwości współpracy Unii Europejskiej z NATO po szczycie w Warszawie" [European Global Strategy and the Possibilities of European Union Cooperation with NATO after the Warsaw Summit]. Bezpieczeństwo Narodowe, $\quad$ I-IV-2016/37-40, 67-83. https://www.bbn.gov.pl/ftp/dok/03/37-40_KBN_Wroblewska.pdf.

25. Zięba, R. (2016). "Współczesne wyzwania i zagrożenia dla bezpieczeństwa międzynarodowego" [Contemporary Challenges and Threats to International Security]. Stosunki Międzynarodowe - International Relations, 3(52), 9-31. doi: 10.7366/02090961320160. 